Marketing in Asia Group

\title{
Editorial - Responsible Tourism: A Call to Action for Turbulent Times
}

\section{Hiram Ting}

Faculty of Hospitality and Tourism Management, UCSI University, Malaysia

\section{Lim Xin Jean}

School of Business and Economics, Universiti Putra Malaysia, Selangor, Malaysia

\section{Leong Choi Meng}

Faculty of Business and Management, UCSI University, Sarawak, Malaysia

\section{Jun-Hwa Cheah}

School of Business and Economics, Universiti Putra Malaysia, Selangor, Malaysia

\section{Joseph M. Cheer}

Center for Tourism Research, Wakayama University, Japan

\begin{abstract}
The magnitude in which global crises and the ongoing societal challenges affects our life has called for attentions to be more socially responsible, environmentally friendly and caring for the wider community. A lot has been said recently about tourism restart or recovery as a consequence of COVID-19, highlighting the need for greater pragmatism and responsibility in the midst of turbulence, further emphasising the relevance for responsible tourism practice and scholarship. The present editorial serves as a foundation that provides an overview of the development of responsible tourism, offering a synthesis of key literature and sources regarding responsible tourism that can help guide future investigations. A bibliometric analysis of responsible tourism was conducted in Web of Science (WOS) database and subsequently 94 articles were used in the final review. While the results show the relevance of sustainable practices, behavioural factors and value creation by multiple stakeholders, they underscore the need for more and better efforts to delve into and realise responsible tourism in the contemporary environment.
\end{abstract}

Keywords: Responsible Tourism, Sustainability, COVID-19, Value, Stakeholders, Behaviour

Publication Details: Received 1 June 2020; Revised 17 Aug 2020; Accepted 30 Aug 2020 


\section{Background}

We are now living in a world of heightened "responsibilities" where mindfulness about the consequences of our collective actions has taken on new urgency, doubtless spurred by climate change and global warming and more recently COVID-19. The manner in which global crises and the ongoing societal challenges tied to it affects our life are reminders to be more socially responsible, environmentally friendly and caring for the wider community. As early as the 1970s, George Young highlighted the inherent contestations arguing that the impact of tourism was both a blessing and a blight (Young, 1973). Despite the apparent benefits tourism convey to countries, organisations and individuals, critics have more intensely called for "more responsibility for the effects of travel and behaviour on host environment, both physical and human" (Butler \& Pearce, 1995, p.5). The direct and indirect effects of tourism preceding COVID-19, remain immense and the repercussions for stakeholders continue to raise concern (Postma \& Schmuecker, 2017; Kocak, Ulucak \& Ulucak, 2020). A lot has been said recently about tourism restart or recovery as a consequence of COVID-19, highlighting the need for greater pragmatism and responsibility, further emphasising the relevance for responsible tourism practice and scholarship.

Sustainable tourism is the umbrella term used to examine the economic, environmental and social needs of all stakeholders and how its impacts might be mitigated (Buckley, 2012; Hall et al., 2015; Waligo et al., 2013). Accordingly, the United Nations World Tourism Organisation (UNWTO) remit is appropriately grounded on three main components of sustainability, namely environmental, sociocultural and economic aspects. While sustainable tourism has been widely appropriated to develop a (more) benign tourism model and help address problematic mass tourism issues (Swarbrooke, 1999; Byrd, 2007), it has been criticized for being inadequate or inapplicable in different contexts (Higgins-Desbiolles, 2010; Liu, 2003). For instance, Wheeler (1993, p.121) argued that the "intellectually appealing" concept of sustainable tourism falls short of pragmatic application because it has become a public relations tool to appease criticism about tourism impacts without alleviating the issues that compound adverse outcomes. Similarly, other scholars have also pointed out that the efficiency of sustainable tourism development remains obscure and its practical implementation is not as simple as it implies, thus making much of the tourism industry "alarmingly unsustainable" (Higgins-Desbiolles, 2010, p.117; Chettiparamb \& Kokkranikal, 2012).

The tourism industry, including travel and hospitality sectors, is unequivocally a major contributor to global gross domestic product (GDP). In 2019, the Travel and Tourism sector contributed 10.3 percent of global GDP (World Travel \& Tourism Council, 2020). The increased number of tourists has had profound impacts on resources, environment, businesses, and local communities in tourism destinations (Gomez, 2020). Unfortunately, and at the same time a myriad of adverse impacts has also emerged and particularly, mass tourism and overtourism have resulted in the decline in the quality of touring experience. Worse still, the quality of life of local communities has tended to remain subservient to the pursuit of tourism growth 
(Goodwin, 2016). Tourist destinations that suffer from influx of tourists are having to reconcile conundrums such as overcrowding, disrespectful behaviour, and the displacement of local people (Gomez, 2020). These problematic issues have understandably shifted the attention from tourism promotion to tourism management and development. Accordingly, the calls for more responsible tourism activities and behaviours have intensified over the years so as to make tourism destinations better places to live in and visit (Goodwin, 2016).

Responsible tourism has emerged in recent years to become an oft evoked buzzword, and its re-emergence has been especially prominent during the COVID-19 crisis. In addition to minimizing negative social, economic and environmental impact which sustainable tourism advocates for, responsible tourism emphasises generating greater social and economic benefits for host communities (Frey \& George, 2010; Goodwin \& Francis, 2003). Responsible tourism resonates often when ethical and moral responsibilities of the tourism sector are raised in question (Bramwell et al., 2008; Goodwin, 2011; Blackstock et al., 2008). Harold Goodwin (2011) contends that responsible tourism is more feasible and thus pivotal to making tourism more sustainable: "the idea of responsible tourism has at its core the imperative to take responsibility, to take action; consumers, suppliers, and governments all have responsibilities. The ambition of responsible tourism, to enhance the positive and to reduce the negative... (p.2) .... Responsible Tourism is about everyone involved taking responsibility for making tourism more sustainable" (p. 31). In developing Goodwin's thesis, David Leslie (2012, p. 20) suggests that responsible tourism is "a behavioural trait ... based on the basic principles of respect for others and their environment...". In light of the aforementioned, this editorial serves as a foundation that provides an overview of the development of responsible tourism, offering a synthesis of key literature and sources regarding responsible tourism that can help guide future investigations.

\section{Literature Review}

Given the rise of and the concerns about environmental well-being and the welfare of local communities, responsible tourism has maintained its allure as an important focus of tourism research and practice despite not garnering the same prominence as other aspects of tourism. According to SNV (2009), the international development agency for the Netherlands government, the evidence suggests that tour operators are almost five times as likely to use 'responsible tourism' compared to any alternative labels. Although responsible tourism shares much in common with other 'tourisms' including "sustainable tourism", "volunteer tourism", "heritage or cultural tourism", "ecotourism", "ethical tourism", "pro-poor tourism" and other related forms of socially conscious practices, there are fine distinctions that differentiates it from the other conceptualizations. Table 1 presents a bird's-eye view of responsible tourism in relation to other tourism aspects. Instead of presenting a comprehensive review, selected definitions and emphases are curated to provide baseline understandings. 
Table 1: A Bird's Eye View of Responsible Tourism in relation to other Tourism Aspects

\begin{tabular}{|c|c|c|c|}
\hline Term & Selected Definitions & Some Key Emphases & Additional References \\
\hline Responsible Tourism & $\begin{array}{l}\text { Providing better holiday experiences for guests } \\
\text { and good business opportunities to enjoy better } \\
\text { quality of life through increased socio-economic } \\
\text { benefits and improved natural resource } \\
\text { management (Spenceley et al., 2002). }\end{array}$ & $\begin{array}{l}\text { 1. To assess, monitor and disclose impacts of } \\
\text { tourism development; } \\
\text { 2. To ensure involvement of communities and the } \\
\text { establishment of meaningful economic linkages; } \\
\text { 3. To encourage natural, economic and socio-cultural diversity; } \\
\text { 4. To promote the sustainable use of local resources. }\end{array}$ & $\begin{array}{l}\text { Mihalic (2016); Frey \& } \\
\text { George (2010); Caruana } \\
\text { et al. (2014) }\end{array}$ \\
\hline Sustainable Tourism & $\begin{array}{l}\text { Achieving a particular combination of numbers } \\
\text { and types of visitors, the cumulative effect of } \\
\text { whose activities at a given destination, together } \\
\text { with the actions of the servicing businesses, can } \\
\text { continue and develop into a foreseeable future } \\
\text { without damaging the quality of the environment } \\
\text { on which the activities are based (Middleton, } \\
\text { 1998). }\end{array}$ & $\begin{array}{l}\text { 1. To make optimal use of environmental resources; } \\
\text { 2. To respect the socio-cultural authenticity of host- } \\
\text { communities; } \\
\text { 3. To ensure viable, long-term economic operations, providing } \\
\text { socio-economic benefits to all stakeholders that are fairly } \\
\text { distributed. }\end{array}$ & $\begin{array}{l}\text { Liu (2003); Butler } \\
\text { (1999); Buckley (2010) }\end{array}$ \\
\hline $\begin{array}{l}\text { Volunteer Tourism/ } \\
\text { Voluntourism/ } \\
\text { Goodwill tourism/ } \\
\text { Alternative Tourism }\end{array}$ & $\begin{array}{l}\text { Developing a conscious, seamlessly integrated } \\
\text { combination of voluntary service to a destination } \\
\text { and the best, traditional elements of travel - arts, } \\
\text { culture, geography, history and recreation - in that } \\
\text { destination (Voluntourism.org). }\end{array}$ & $\begin{array}{l}\text { 1. To promote cultural immersion; } \\
\text { 2. To encourage making a difference; } \\
\text { 3. To develop camaraderie; } \\
\text { 4. To enhance family bonding; } \\
\text { 5. To broaden one's mind. }\end{array}$ & $\begin{array}{l}\text { Wearing \& McGehee } \\
\text { (2013); Brown (2005); } \\
\text { Callanan \& Thomas } \\
\text { (2005); Benson \& } \\
\text { Seibert (2009) }\end{array}$ \\
\hline $\begin{array}{l}\text { Heritage Tourism/ } \\
\text { Cultural Tourism }\end{array}$ & $\begin{array}{l}\text { Generating the awareness and appreciation as } \\
\text { well as enhancing the experience of various items, } \\
\text { representative of past and present periods, at a } \\
\text { tourist destination (Bryce et al., 2015). }\end{array}$ & $\begin{array}{l}\text { 1. To care for local natural environment; } \\
\text { 2. To immerse in local culture; } \\
\text { 3. To embrace local heritage. }\end{array}$ & $\begin{array}{l}\text { Park, Choi, \& Lee } \\
\text { (2019); Adongo, Choe, \& } \\
\text { Han (2017) }\end{array}$ \\
\hline Eco-tourism & $\begin{array}{l}\text { Travelling to relatively undisturbed or } \\
\text { uncontaminated natural areas with the specific } \\
\text { objective of studying, admiring and enjoying the } \\
\text { scenery and its wild plants and animals, as well as }\end{array}$ & $\begin{array}{l}\text { 1. To generate awareness about environmental well-being; } \\
\text { 2. To be involved in meaningful ventures; } \\
\text { 3. To sustain tourism and be part of the locals. }\end{array}$ & $\begin{array}{l}\text { Stronza \& Gordillo } \\
\text { (2008); Fennell (2001); } \\
\text { Ross \& Wall (1999) }\end{array}$ \\
\hline
\end{tabular}




\begin{tabular}{|c|c|c|c|}
\hline & $\begin{array}{l}\text { any existing cultural manifestations (both past and } \\
\text { present) found these areas (Ceballos-Lascurain, } \\
\text { 1983). }\end{array}$ & & \\
\hline Ethical Tourism & $\begin{array}{l}\text { Tourists and tourism providers taking } \\
\text { responsibility for their behaviours and attitudes, } \\
\text { with each stakeholder group gaining equity in the } \\
\text { tourism decision-making process (Weeden, 2011). }\end{array}$ & $\begin{array}{l}\text { 1. To increase the awareness of each tourism stakeholder about } \\
\text { their moral responsibility; } \\
\text { 2. To practice moral responsibility in their respective actions. }\end{array}$ & $\begin{array}{l}\text { Malone, McCabe, \& } \\
\text { Smith (2014); } \\
\text { Ganglmair-Wooliscroft, } \\
\text { \& Wooliscroft (2016) }\end{array}$ \\
\hline Pro-poor Tourism & $\begin{array}{l}\text { An approach to tourism development and } \\
\text { management which ensures that local poor people } \\
\text { are able to secure economic benefits from } \\
\text { tourism in a fair and sustainable manner } \\
\text { (Goodwin \& Francis, 2003) }\end{array}$ & $\begin{array}{l}\text { 1. To ensure economic gain for the poor through employment } \\
\text { and micro-enterprise development; } \\
\text { 2. To ensure infrastructure gains such as roads, water, } \\
\text { electricity and telecommunications; } \\
\text { 3. To empower them through engagement in decision-making. }\end{array}$ & $\begin{array}{l}\text { Chok, Macbeth, \& } \\
\text { Warren (2007); Ashley } \\
\text { \& Roe (2001) }\end{array}$ \\
\hline
\end{tabular}


In the 1990s, Wheeller (1990), for instance, asserted that the concept of responsible tourism emerged in response to concerns about the impact of mass tourism development, and as a means of distinguishing between 'alternative' forms of tourism. Extant literature also highlights that responsible tourism is not a replacement term for sustainable tourism per se. In fact, it is not a new term, but neither a novel alternative to other forms of tourism or a new way of "executing" sustainable tourism (Blackstock et al., 2008, p. 279). Specifically, responsible tourism can be developed with many different initiatives in mind, particularly those based on the priorities and specific contexts of the destinations. The focal point and the goal of these initiatives are to create a conducive tourism environment that allows the parties involved to provide economic benefits more equitably for the wider global community, in particular groups at the base of socio-economic hierarchies. Hence it is imperative that new ventures be designed in order to be inclusive and engage with different socio-cultural values and enable environmentally-friendly economic policy frameworks for more fecund futures.

Responsible tourism revolves around the idea that tourism can and should bring about positive benefits to local stakeholders, as well as the natural, and business environment (Frey $\&$ George, 2010). There are a number of industry protocols regarding responsible tourism which look to describe or define its key components. Most significantly, the 2002 Cape Town Declaration, arguably still relevant today, characterizes responsible tourism in terms of minimizing negative impacts, generating optimum economic benefits and enhancing wellbeing of local people, involving them in decision making, conserving natural and cultural heritage, providing meaningful connections between tourists and local people, offering access for people with disabilities and the disadvantaged and being accessible and culturally sensitive (World Tourism Market Responsible Tourism, 2013).

In its simplest form, responsible tourism advocates for "making better places for people to live in and better places for people to visit" (Goodwin, 2014a). The fundamental tenet is that the monetary value of tourism should also aid conservation, poverty improvement, and economic support to the destinations, either via direct or indirect means (Shannon, 2019). It concerns taking pragmatic approaches as more often than not, tourists' considerations and choices can have direct impacts on the local environment and communities in situ. Moreover, responsible tourism is a call-to-action, particularly from operators, hoteliers, governments, residents and tourists to achieve mutually beneficial goals (Goodwin, 2014a). One of the pioneers in adopting responsible tourism strategy is South Africa where stakeholders are challenged to assume their collective responsibility to promote healthy tourism initiatives and practices (Goodwin, 2014b). 


\section{Methods}

To gain insights into the trend of responsible tourism, we conducted a bibliometric analysis in Web of Science (WOS) database as shown in Figure 1. Given the exploratory nature of the study, the query: TS= ("responsible tourism") alone was used. The analysis was conducted in mid-August and subsequently 256 articles were found in WOS. However, 162 articles were excluded because they were not research articles and/or were not written in English. Hence, 94 articles were retained in the final review, including those using the term "responsustable tourism".

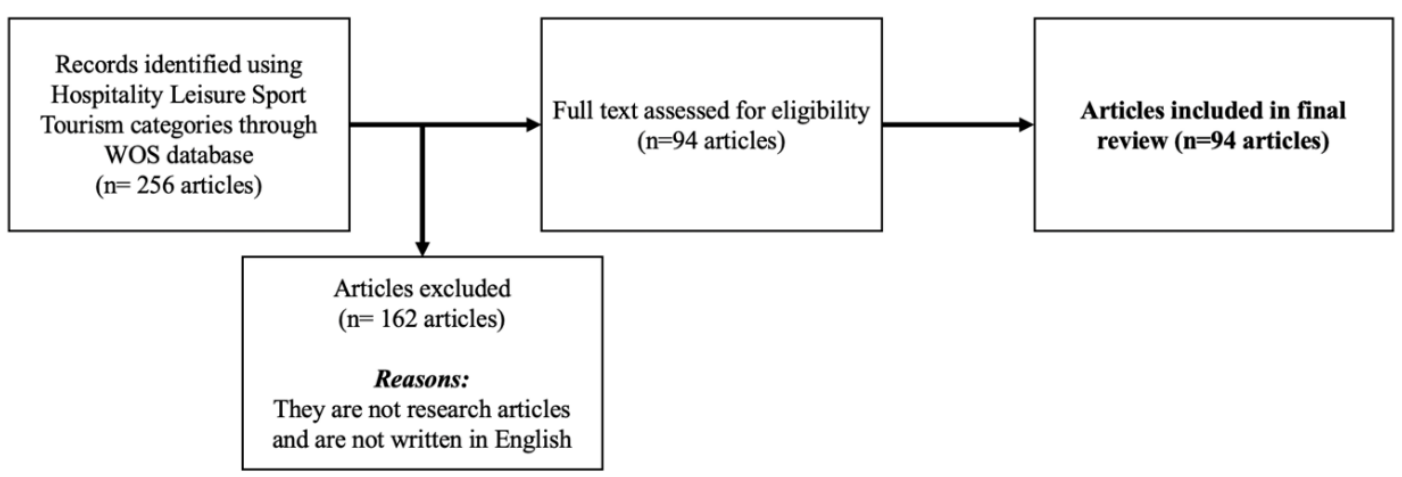

Figure 1: Procedure and criteria in selecting articles from WOS database

\section{Discussions}

The findings show a total of 94 articles looking into responsible tourism are published in tourism (including hospitality, leisure and sport) categories with accumulated citations of 1,131 (or 12.03 citations per paper in average) by mid-August 2020. The first evident publication pertaining to responsible tourism is dated back to 1993, and it was published in Annals of Tourism Research, one of top journals in tourism and hospitality disciplines. Surprisingly, no significant work about responsible tourism is found between 1994-2006. As shown in Figure 2, there is, however, a substantial increase of the number of articles related to responsible tourism published between 2007 and 2012. Among the 94 articles, 13 of them were published in 2014 but the number dropped to five in 2015 before surging to 14 in the following year. In average 10 articles were published in the next three years. Based on the publication trend, the number should increase significantly by the end of 2020 as there are already 10 articles on responsible tourism published by mid-August 2020 . 


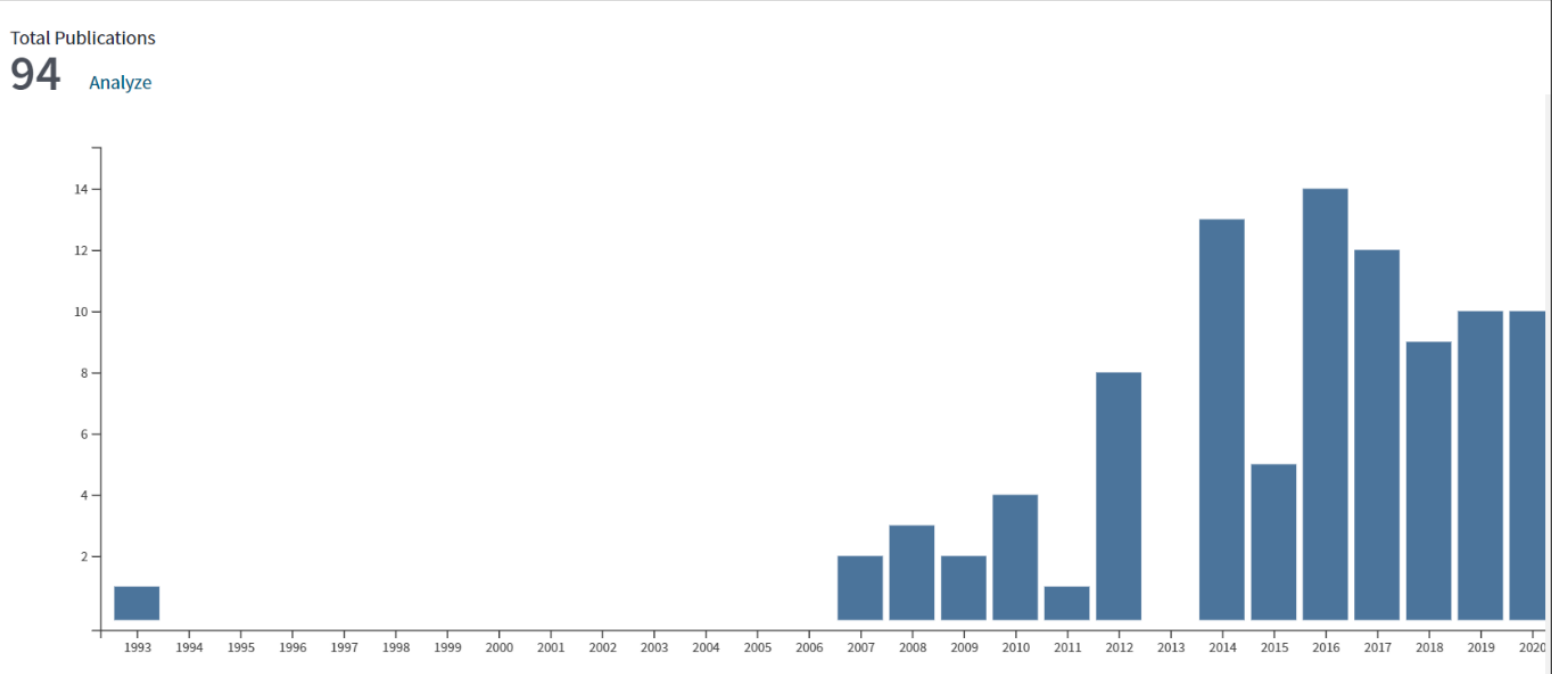

Figure 2: Number of papers by year published

In terms of journal citation structure, there is a considerable and steady increase of citations for responsible tourism related articles over the last two decades. It started with one citation in 1997 to 284 in 2019. To date, the accumulated number of citations of articles related to responsible tourism stand at 1,131. Referring to Figure 3, the period between 1997-2010 can be regarded as an initiation phase where the number of citations was below 20 before it went up to 31 citations in 2011. Thus, the period between 2011 and 2019 can be seen as a development phase where the number of citations has shown a significant increase, thus suggesting the growing interest of scholars in this particular subject. Although there are still four months left before 2020 ends, 2020 and onwards can be postulated as another phase where responsible tourism will grow as one of the most critical tourism topics and most improved tourism research by citation structure.

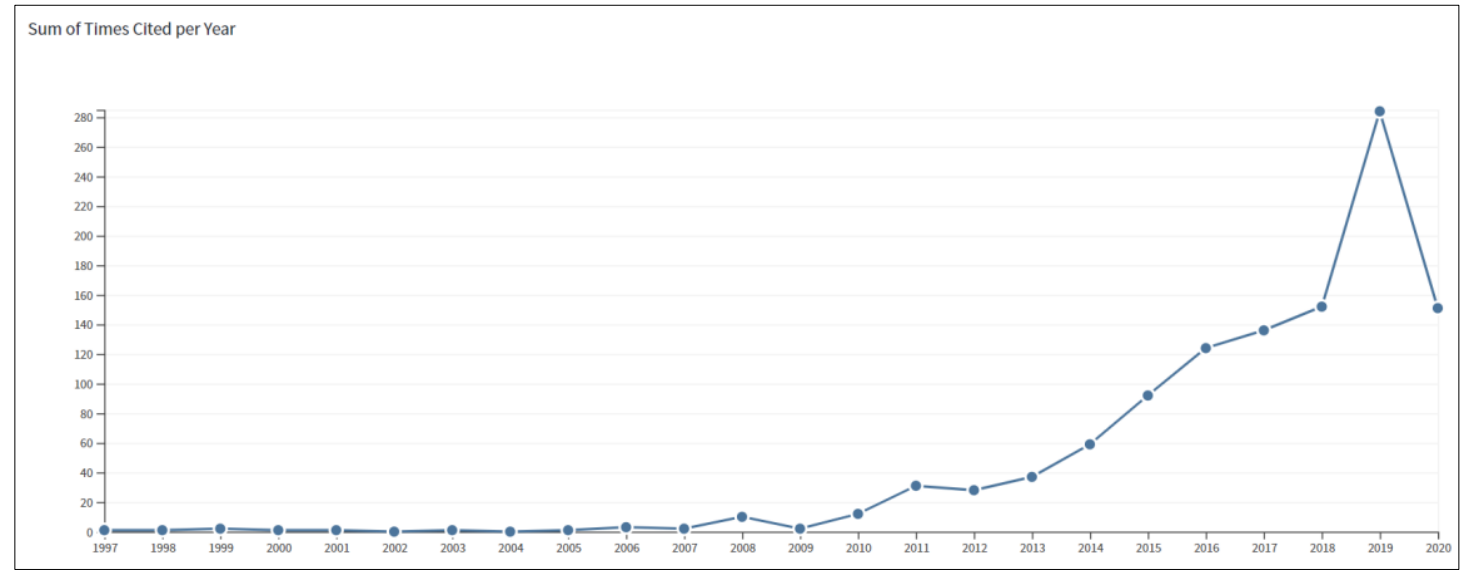

Figure 3: Yearly Citation Structure 
To further analyse the published articles, a visual analysis on co-occurrence of author keywords via VOS viewer was conducted (Eck \& Waltman, 2014). Using three keywords as a minimum criterion, it is observed that the keyword trend changes moderately over the years. Based on the graphical display as shown in Figure 4, the relationship of the keywords used by the authors can be divided into six clusters. The node with the highest number of keywords (with 13 key items) is led by sustainability. Most of the keywords in this node are related to destination, community, community development, ecotourism, policy and participation. This implies responsible tourism is mostly related to sustainability and community or destination development. The second node is led by management (with seven key items). This node is found to be connected to attitude, behaviour, corporate social responsibility, ethics, and operators. The findings suggest the relevance of behaviours and actions to responsible tourism. The third node is led by values (with seven key items). This node ties in with co-creation, destination image, identity, motivation, and model. This indicates the importance of stakeholders and how they can create value through concerted effort. The fourth node is led by perceptions and it is linked to the concept of volunteer tourism, sustainable development, quality and impact. This shows that the sense of responsibility through awareness or practice matters to responsible tourism. The fifth node is led by sustainable tourism which is linked to community-based tourism, slum tourism, poverty alleviation, and business. The emphasis is on sustainable practices. Lastly, the sixth node is led by Africa and it is associated with challenges and tourism development. It refers to South Africa where the 2002 Cape Town Declaration was made and responsible tourism development is often made reference to.

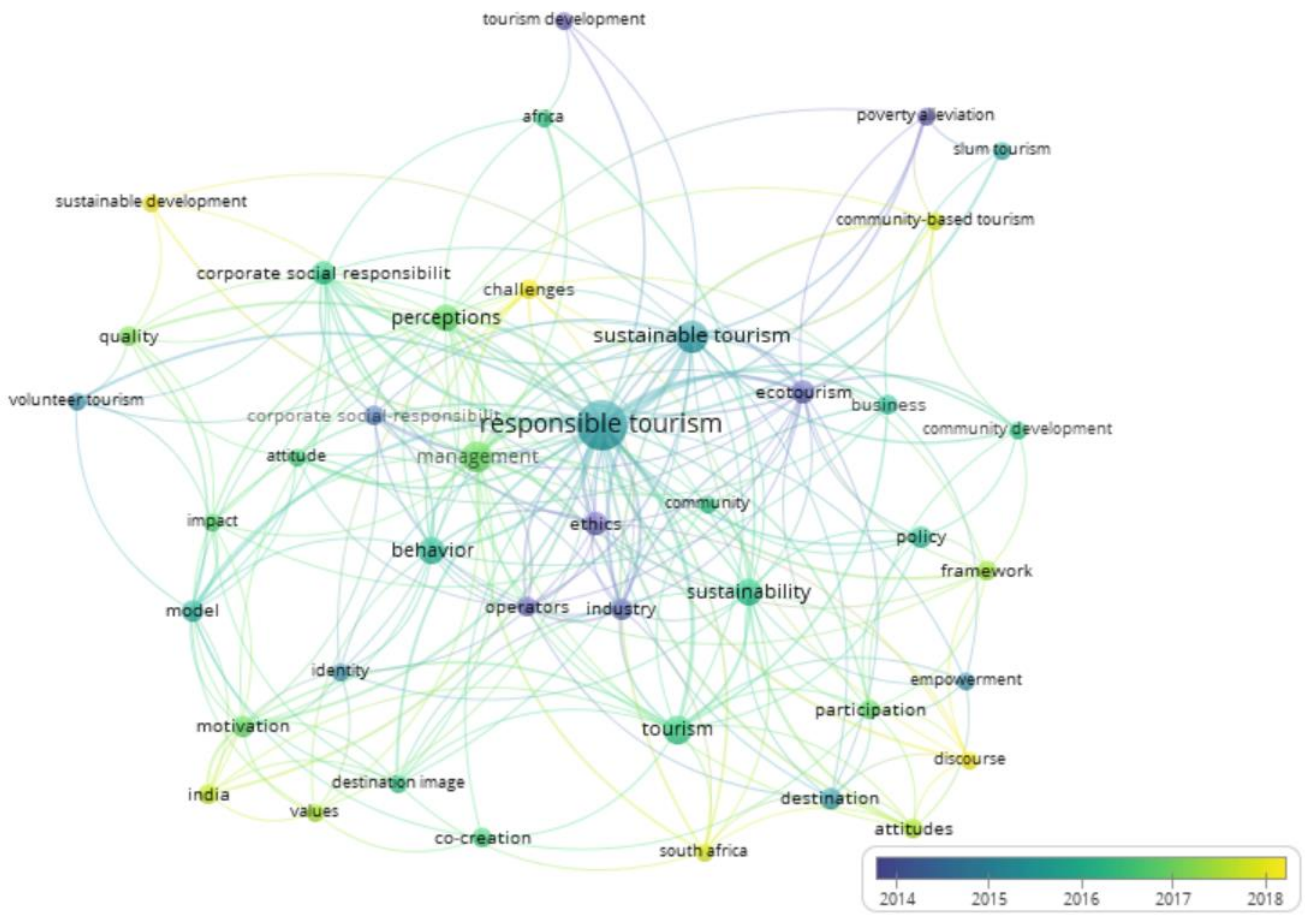

Figure 4: Co-occurrence of author keywords figure produced in VOS viewer software 


\section{Implications and Conclusion}

The present editorial provides an overview of responsible tourism. In particular it presents the background of responsible tourism in relation to other tourism aspects as well as its development in research and practice. Although the study is by no means comprehensive, we believe that it is an important step to affirm the relevance of responsible tourism in the contemporary environment and pave the way for more investigations from scholars and practitioners in the future.

We are of the opinion that responsible tourism is not a synonym nor a replacement for sustainable tourism. While sustainable tourism looks at the macro aspects of tourism development, responsible tourism delves into the micro aspects; and they should complement each other. Based on the earlier findings and discussions, responsible tourism is very much related to sustainability and sustainable practices. However, it goes on to underline the significance of management, and perceptions and their relations to behavioural factors, such as attitude, corporate social responsibility and doing good (as in volunteer tourism), not only to reduce their negative impacts but also to generate positive solutions to problems. Far from being the sole responsibility of tourists or visitors, it highlights the magnitude of the roles and actions of multiple stakeholders to create corporate value and bring benefits to the environment and the people concerned. When working together in unison to weather challenges and achieve collective objectives, it is imperative that self-interests are put aside and priorities are well determined, and accepted among the stakeholders. Furthermore, as responsible tourism is also about making sure that the socio-economic welfare of specific communities is improved through tourism activities, it implies that sustainable practice should not be seen as something universal. What works in one place might not necessarily be applicable to another place due to difference in demographics, social structure and other contextual factors. As such specific priorities should be articulated based on the setting and responsible behaviour taught or guided on the ground to make any initiatives sustainable.

It goes without saying that the present pandemic and the turbulence it causes have had an unprecedented effect on tourism and hospitality industry. It causes uncertainty in many ways as well as health and safety concerns in traveling. While confidence and willingness to travel will take some time to recover, we believe a lot can be done to realize responsible tourism even when borders are closed and movement is restricted. For example, content marketing as a means of interactive communication can be a valuable tool to promote social and environmental responsibility in tourism (Xiang \& Gretzel, 2010). Involving (potential) tourists in online conversations about responsible tourism to form any collaborative efforts to raise awareness about environmental issues or generate interest in feasible sustainable practices in certain places can be effectively done via social media (Waligo, Clarke \& Hawkins, 2013). Moreover, augment reality (AR) and virtual reality (VR) can be a useful tool to facilitate individuals' experience as responsible tourists or travelers (Jung, tom Dieck, Lee \& 
Chung, 2016). While these technologies help to increase destination competitiveness (De Paola, 2018; Marasco, Buonincontri, van Niekerk, Orlowski \& Okumus, 2018), they can certainly be useful to help tourists to first practice responsible tourism in a virtual environment, such as a cultural or historical site. Although crisis breeds innovation and creativity, and tourism restart requires embracement of change and new norms, the onus is still on us and the stakeholders to use them and implement them responsibly.

\section{References}

Adongo, R., Choe, J.Y., \& Han, H., (2017), "Tourism in Hoi An, Vietnam: Impacts, perceived benefits, community attachment and support for tourism development", International Journal of Tourism Sciences, vol. 17, no. 2, pp. 86-106.

Ashley, C., \& Roe, D., (2001), Pro-poor tourism strategies: Making tourism work for the poor: A review of experience (No. 1), Iied, London.

Benson, A., \& Seibert, N., (2009), "Volunteer tourism: motivations of German participants in South Africa", Annals of Leisure Research, vol. 12, no. 3-4, pp. 295-314.

Blackstock, K.L., White, V., McCrum, G., Scott, A., \& Hunter, C., (2008), "Measuring responsibility: An appraisal of a Scottish National Park's sustainable tourism indicators", Journal of Sustainable Tourism, vol. 16, no. 3, pp. 276-297.

Bramwell, B., Lane, B., McCabe, S., Mosedale, J., \& Scarles, C., (2008), "Research perspectives on responsible tourism". Journal of Sustainable Tourism, vol. 16, no. 3, pp. 253-257.

Brown, S., (2005), "Travelling with a purpose: Understanding the motives and benefits of volunteer vacationers", Current Issues in Tourism, vol. 8, no. 6, pp. 479-496.

Bryce, D., Curran, R., O'Gorman, K., \& Taheri, B. (2015), "Visitors' engagement and authenticity: Japanese heritage consumption," Tourism Management, vol. 46, pp. 571581.

Buckley, R. C., (2010), Conservation tourism, CAB International, Wallingford.

Buckley, R., (2012). "Sustainable tourism: Research and reality", Annals of Tourism Research, vol. 39, no. 2, pp. 528-546.

Butler, R., \& Pearce, D. G. (eds.), (1995). Change in tourism: people, places, processes, London: Routledge.

Butler, R., (1999), "Sustainable tourism: A state-of-the-art review", Tourism Geographies, vol. 1 , no. 1 , pp. 7-25.

Byrd, E.T., (2007), "Stakeholders in sustainable tourism development and their roles: applying stakeholder theory to sustainable tourism development", Tourism Review, vol. 62 , no. 2 , pp. 6-13.

Callanan, M., \& Thomas, S., (2005), "Volunteer tourism”, Niche tourism, pp.183-200.

Caruana, R., Glozer, S., Crane, A., \& McCabe, S., (2014), "Tourists' accounts of responsible tourism", Annals of Tourism Research, vol. 46, pp. 115-129.

Ceballos-Lascurain, H., (1983), Tourism, ecotourism and protected areas, In J. A. Kusler (ed.), Ecotourism and resource conservation, vol. 1, Ecotourism Conservation Project. Merida, Mexico, Berne, N.Y, pp. 24-34.

Chettiparamb, A., \& Kokkranikal, J., (2012), "Responsible tourism and sustainability: the case of Kumarakom in Kerala, India", Journal of Policy Research in Tourism, Leisure and Events, vol. 4, no. 3, pp. 302-326.

Chok, S., Macbeth, J., \& Warren, C., (2007), "Tourism as a tool for poverty alleviation: A critical analysis of 'pro-poor tourism' and implications for sustainability", Current Issues in Tourism, vol. 10, no. 2-3, pp. 144-165. 
De Paola, F., (2018), La destination France s'anime en realite augmentee, Retrieved from https://www. lechotouristique.com/article/la-france-se-montre-en-realite-augmentee

Fennell, D.A., (2001), "A content analysis of ecotourism definitions", Current Issues in Tourism, vol. 4, no. 5, pp. 403-421.

Frey, N., \& George, R., (2010), "Responsible tourism management: The missing link between business owners' attitudes and behaviour in the Cape Town tourism industry", Tourism Management, vol. 31, no. 5, pp. 621-628.

Ganglmair-Wooliscroft, A., \& Wooliscroft, B., (2016), "Diffusion of innovation: The case of ethical tourism behaviour", Journal of Business Research, vol. 69, no. 8, pp. 27112720.

Gomez, T., (2020), What is Responsible Tourism and Why is It Important?, Retrieved from https://broganabroad.com/what-is-responsible-tourism/

Goodwin, H., \& Francis, J., (2003), "Ethical and responsible tourism: Consumer trends in the UK", Journal of Vacation Marketing, vol. 9, no. 3, pp. 271-284.

Goodwin, H., (2011), Taking responsibility for tourism (p. 256), Woodeaton: Goodfellow Publishers Limited.

Goodwin, H., (2014a), What is responsible tourism?, Retrieved from https://responsibletourismpartnership.org/what-is-responsible-tourism/

Goodwin, H., (2014b), Responsible tourism in destinations - introduction, Retrieved from https://responsibletourismpartnership.org/conferences/responsible-tourism-indestinations-introduction/

Goodwin, H., (2016), OverTourism: What is it and how do we address it?, Retrieved from https://responsibletourismpartnership.org/overtourism/

Hall, C.M., Amelung, B., Cohen, S., Eijgelaar, E., Gössling, S., Higham, J., Leemans, R., Peeters, P., Ram, Y., Scott, D., \& Aall, C., (2015), "Denying bogus skepticism in climate change and tourism research", Tourism Management, vol. 47, pp. 352-356.

Higgins-Desbiolles, F., (2010), "The elusiveness of sustainability in tourism: The cultureideology of consumerism and its implications", Tourism and Hospitality Research, vol. 10, no. 2, pp. 116-129.

Jung, T., tom Dieck, M.C., Lee, H., \& Chung, N., (2016), "Effects of virtual reality and augmented reality on visitor experiences in museum, In Information and Communication Technologies in Tourism 2016, Springer, Cham, pp. 621-635.

Koçak, E., Ulucak, R., \& Ulucak, Z.Ş., (2020), "The impact of tourism developments on CO2 emissions: An advanced panel data estimation", Tourism Management Perspectives, vol. 33, p. 100611.

Leslie, D. ed., (2012), Responsible tourism: Concepts, theory and practice, CABI.

Liu, Z., (2003), "Sustainable tourism development: A critique", Journal of Sustainable Tourism, vol. 11 , no. 6, pp. 459-475.

Malone, S., McCabe, S., \& Smith, A.P., (2014), "The role of hedonism in ethical tourism", Annals of Tourism Research, vol. 44, pp. 241-254.

Marasco, A., Buonincontri, P., van Niekerk, M., Orlowski, M., \& Okumus, F., (2018), "Exploring the role of next-generation virtual technologies in destination marketing", Journal of Destination Marketing \& Management, vol. 9, pp. 138-148.

Middleton, V., (1998), Sustainable tourism: A marketing perspective, Butterworth Heinemann, Oxford.

Mihalic, T., (2016), "Sustainable-responsible tourism discourse-Towards 'responsustable' tourism", Journal of Cleaner Production, vol. 111, pp. 461-470.

Park, E., Choi, B.K., \& Lee, T.J., (2019), "The role and dimensions of authenticity in heritage tourism", Tourism Management, vol. 74, pp. 99-109.

Postma, A., \& Schmuecker, D., (2017), "Understanding and overcoming negative impacts of tourism in city destinations: conceptual model and strategic framework", Journal of Tourism Futures, vol. 3, no. 2, pp. 144-156.

Ross, S., \& Wall, G., (1999), "Ecotourism: towards congruence between theory and practice", Tourism Management, vol. 20, no. 1, pp. 123-132. 
Shannon, (2019), 8 Behaviours of responsible travellers, Retrieved from http://blog.grassrootsvolunteering.org/responsible-travel/

SNV, (2009), The market for responsible tourism products: SNV Netherlands development organization, Retrieved from http://www.snvworld.org/en/publications/the-market-forresponsible-tourism-products

Spenceley, A., Relly, P., Keyser, H., Warmeant, P., McKenzie, M., Mataboge, A., et al. (2002), Responsible Tourism Manual for South Africa, Department for Environmental Affairs and Tourism, Pretoria.

Stronza, A., \& Gordillo, J., (2008), "Community views of ecotourism", Annals of Tourism Research, vol. 35 , no. 2, pp. 448-468.

Swarbrooke, J., (1999), Sustainable tourism management, CABI.

van Eck N, \& Waltman L, (2014), Visualizing bibliometric networks, In: Ding Y, Rousseau R, Wolfram D (eds), Measuring scholarly impact, Springer International Publishing, Berlin, pp. 285-320.

Waligo, V.M., Clarke, J., \& Hawkins, R., (2013), "Implementing sustainable tourism: A multi-stakeholder involvement management framework", Tourism Management, vol. 36, pp. 342-353.

Wearing, S., \& McGehee, N.G., (2013), "Volunteer tourism: A review", Tourism Management, vol. 38, pp. 120-130.

Weeden, C., (2011), "Responsible tourist motivation: How valuable is the Schwartz value survey?", Journal of Ecotourism, vol. 10, no. 3, pp. 214-234.

Wheeler, M., (1993), "Tourism marketers in local government", Annals of Tourism Research, vol. 20, pp. 354-356.

Wheeller, B., (1990), "Responsible tourism", Tourism Management, vol. 11, vol. 3, pp. 262263.

World Tourism Market Responsible Tourism (2013), About WTM responsible tourism, Retrieved from http://www.wtmresponsibletourism.com/Content/About-WTMResponsible-Tourism

World Travel \& Tourism Council (2020), Travel \& Tourism - Global Economic Impact \& Trends 2020, Retrieved from www.wttc.org

Xiang, Z., \& Gretzel, U., (2010), "Role of social media in online travel information search," Tourism Management, vol. 31, no. 2, pp. 179-188.

Young, G., (1973), Tourism blessing or blight? Penguin Books, Inc., Baltimore. 